\title{
The Multiple Social Functions of the Mobile Phone in the Mozambican Communities
}

\author{
Joanguete Celestino \\ Eduardo Mondlane University/- School of Communication and Arts, Maputo, Mozambique
}

How to cite this paper: Celestino, J. (2018). The Multiple Social Functions of the Mobile Phone in the Mozambican Communities. The Educational Review, USA, 2(5), 309-319. http://dx.doi.org/10.26855/er.2018.05.005

Corresponding author: Joanguete Celestino, Eduardo Mondlane University/School of Communication and Arts, Maputo, Mozambique.

\begin{abstract}
The aim of the study is to explore the potential of the telephone in the Mozambican social ecosystem, in particular, in multiple social functions in the new realities, Mozambique, particularly in the processes of electronic transactions, monitoring of governance and strengthening of the media to reach new audiences previously margin-alized by traditional means of communication. Based on empirical studies by UNESCO entitled Reading in the Mobile Age and research entitled The Evolution of Information Systems in Africa: A Road to Security and Stability, the article proposes to reflect on the three aspects: the role of cellular in social, economic and policies.

The study mapped the impacts of cell phones on society, supporting arguments that support the inclusion of "marginalized" communities in the digital society. The structure of work is built on 5 fundamental points that revolve around the mobile phone: Communication in general; financial system; monitoring of governance; agriculture and the media. All points have led us to the fact that the mobile phone is one of the devices that is operating political transformations, through the civic engagement of the citizen; financial inclusion of the citizen through the facilitation of basic transactions and savings and the revaluation of the media, in particular, the community radios through telephone transmission.
\end{abstract}

\section{Keywords}

Mobile Phone. Communication, Media, Rural and Multiple Functionalities

\section{Introduction}

The purpose of this paper is to analyze the multiple social functions of mobile phones in Mozambican communities, highlighting their potential in strengthening policies for financial inclusion, monitoring of governance, food security, radio signal transmission and, in general, in interpersonal communication.

In recent years there has been a growth of the mobile telecommunications sector in Mozambique, due to the investment of the operating companies. More than 19.223516 users joined the services, representing a penetration rate of $26.02 \%$, as well as the geographic coverage of the entire national territory (INE, 2017). The scenario of mobile phone massification can point to the main problems of the Mozambican rural community, especially the weak interpersonal communication between the countryside/city; financial exclusion of the rural population; food insecurity; of Community Radios in the face of technological advances.

The research is based on the following question: How is the mobile phone transforming the Mozambican social ecosystem, namely in the communicative process, in the control of governance, in radio transmission, in the financial inclusion 
of the rural population and in food security?

In light of the vast literature on mobile telephony in Africa such as: Mobile Technologies and Empowerment, Turning on Mobile Learning in Africa and the Middle East Illustrative Initiatives and Policy Implications (2012); Reading in Mobile Era (2014), and the Mobile Africa Report (2014); Mobile media services at Sub-Saharan African newspapers: A guide to implementing mobile news and mobile business and the book The Mobile Economy Sub-Saharan Africa 2014 support all the arguments in this study that synthesize knowledge about the articulation between mobile phone and development social sectors such as finance, media, politics and food security.

We intend to study the multiple functions of the mobile phone because $70 \%$ of the rural population is excluded from basic services, and another reason is associated with the fact that the mobile phone is less exploited by the Mozambican scientific community.

In this study, we reflect analytically on the concept of technological convergence, as pointed out by Jenkins (2008), which materializes in the mobile phone. From this, the study explores how to strengthen the continuity of radio in the digital age, in which it seeks a greater understanding of the potential of mobile phones and their accessibility to the rural community. It is intended to understand the contours of the relationship between radio and mobile phone, transmission processes and citizen participation, paying special attention to the changes that can transform it into a citizen engaged in society.

The research combines the theoretical discussion and field study, which resulted in an exercise that served to deepen the understanding about the subject and to know the impacts of mobile communication in the Mozambican communities, namely, the contributions that it represents for active and participative citizenship. In this sense, we discuss the main scenarios of the study that mobile phones are introducing social transformations in Mozambican rural communities, thanks to the investments of the telecommunications infrastructure of the mobile phone companies to the interior areas. In order to reach the results of the study on the mobile phone and the reinforcement of Community Radios, RC, we will apply the methodological strategy based on the bibliographic review.

\section{Background}

According to CEPAL's studies entitled La Nueva Revolucion Digital, published under the auspices of the United Nations in June 2015, it indicates that in 2014 it was estimated that there were 3.6 billion people subscribing to mobile telephony services in the world and 2,923 million of people used the Internet.

One of the factors of the massification of the telephone by the African population is due to the expansion of the telecommunication infrastructures for the rural areas and the consequent competition between the companies that supply services. While in Mozambique, mobile phone success is associated with the above motives and the cheapness of mobile devices, thanks to the massive penetration of these devices Africa / China commercial products.

In the area of financial inclusion, mobile money continues to expand throughout sub-Saharan Africa and has been a key tool in recent decades. There were 140 mobile finance services in 2016 in 39 countries, almost 280 million registered accounts and about 1.5 million registered agents. (GSMA, 2018, p. 41).

As the Figure 1 illustrates, in 2017 Mozambique competes with 33\% remittances via mobile money compared to Tanzania with $68 \%$ and Kenya $73 \%$. These data are indicative of Mozambique's third position in Africa in the use of mobile money and financial inclusion of the populations living in rural areas.

In agriculture, the mobile phone is assuming the important role in providing information to small rural farmers, allowing them better investments and decisions. For example, In June 2015, Vodafone Ghana launched the Vodafone Farmers' Club-a package of agricultural advisory services, weather updates and market prices delivered via SMS. As of December 
2016, there were more than 200,000 registered farmers. (GMSA, 2018, p.41).

\title{
Mobile money use cases
}

\author{
Percentage of respondents (smartphone and non-smartphone users) \\ performing activity at least once per month over mobile
}

Online banking

Bill payment

Remittances via mobile money services

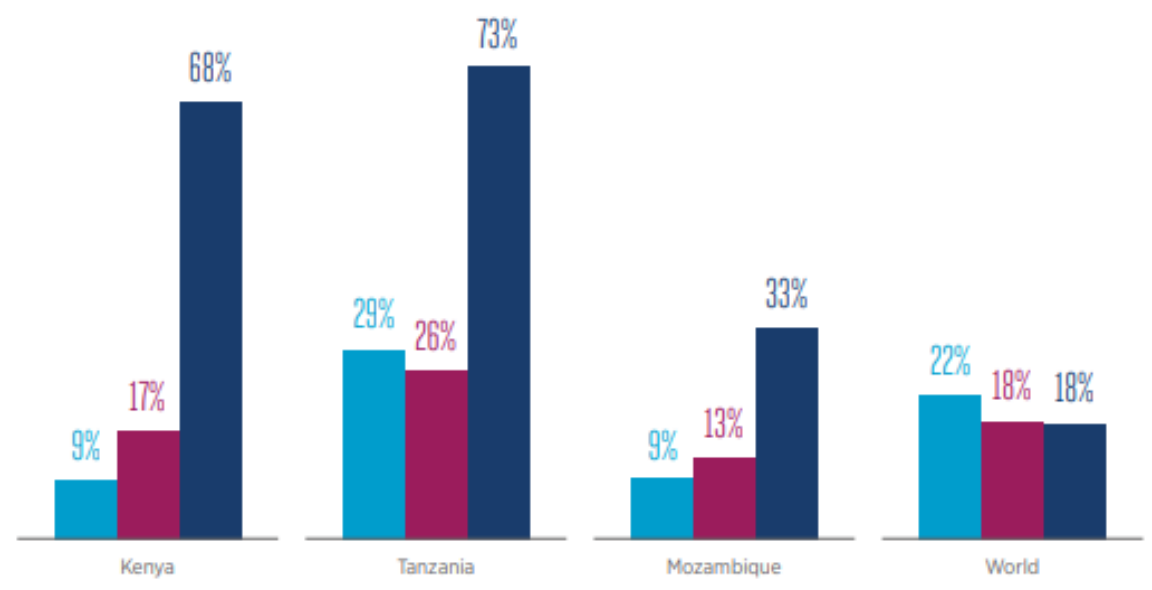

Figure 1.Source: GSMA (2018).

The massification of social technologies and telecommunications infrastructures has increased the global flow of communication (Hamelink, 1998), consequently reduced transaction costs, production and distribution of digital goods and services.

The World Bank report on Mozambique is looking at the analysis of the impacts of the mobile phone in the fight against urban poverty. The report says the World Bank intends to assess how much resilience to weather conditions is being reinforced by the use of mobile phones, particularly to alert governments to local sanitation and drainage problems as well as mapping communities.

The scenario of mobile telephony services has been growing dramatically in the Mozambican urban environment. In particular, there is growth in payments for services and bank transfers; monitoring of governance and strengthening of the media. This growth means that mobile phone services are reaching rural levels and digital inclusion of the previously marginalized population.

As the chart illustrates, in 2017 Mozambique competes with 33\% remittances via mobile money compared to Tanzania with $68 \%$ and Kenya $73 \%$. These data are indicative of Mozambique's third position in Africa in the use of mobile money and financial inclusion of the populations living in rural areas.

In agriculture, the mobile phone is assuming the important role in providing information to small rural farmers, allowing them better investments and decisions and investments. For example, In June 2015, Vodafone Ghana launched the Vodafone Farmers' Club-a package of agricultural advisory services, weather updates and market prices delivered via SMS. As of December 2016, there were more than 200,000 registered farmers. (GMSA, 2018, p.41)

The massification of social technologies and telecommunications infrastructures has increased the global flow of communication (Hamelink, 1998), consequently reduced transaction costs, production and distri-bution of digital goods and 
services.

The World Bank report on Mozambique is looking at the analysis of the impacts of the mobile phone in the fight against urban poverty. The report says the World Bank intends to assess how much resilience to weather conditions is being reinforced by the use of mobile phones, particularly to alert governments to local sanitation and drainage problems as well as mapping communities.

The scenario of mobile telephony services has been growing dramatically in the Mozambican urban environment. In particular, there is growth in payments for services and bank transfers; monitoring of governance and strengthening of the media. This growth means that mobile phone services are reaching rural levels and digital inclusion of the previously marginalized population.

\section{Results}

\subsection{Mobile Communication in Mozambican Rural Areas}

In recent years, the mobile telecommunications sector in Mozambique has grown significantly due to the investment of the operating companies and thanks to the expansion of telecommunications infrastructures and the purchasing power of the citizen.

ACIST (2016) in 1997, telecommunications services recorded an average of 65,606 subscribers for fixed-line services and 2,500 mobile telephone subscribers. At that time the market was dominated only by two companies: Telecomunicações de Moçambique, TDM, for fixed services and Moçambique Celular, MCEL, for mobile services. The approval of the Basic Telecommunications Law, Law 14/99, of 1 December and the reform of the telecommunications sector in 2002, the telecommunications landscape changed radically with the entry of the new mobile services company, VODACOM-Mozambique, in 2003 the most dynamic and competitive market and, consequently, the stifling of the only state-owned fixed services company, TDM, (ACIST, 2016).

Currently, mobile operators such as MCEL holds 5.3 million users, it remains the most urbanized company along with VODACOM Mozambique holding 3 Million Users. A third mobile company, MOVITEL, entered the market in 2012, which results from the partnership between the Mozambican group SPI-Gestão e Investimentos (20\%), IVESPAR (10\%), subsidiary of the SPI group and the company VIETTEL (70\%). , 100\% controlled by the Ministry of Defense of Vietnam. MOVITEL initially invested 177 million dollars, having installed 12,500 Kilometers of the optical fiber and 1,800 base stations for the $2 \mathrm{G}$ and $3 \mathrm{G}^{1}$ networks. Movitel was the first to move to the most remote areas of Mozambique through Fiber Optic cable and lines areas.

In 2013, one year after its entry into the market, MOVITEL began operating in more than 78 districts and today it speaks of a strong presence in remote locations. Currently, the company claims to have conquered $80 \%$ of the national mobile network market, with 2 million potential users of the Mozambican rural market.

Through the three companies that operate in the country, Mozambique has a little more than 9.5 million mobile phone users, a number that shows a growth trend for half of the Mozambican population in the coming years.

The massification of the mobile phone in the rural environment is due to the low requirement of the device and the low physical infrastructure, which reduces the costs of investment and accelerated penetration in rural areas in a more profitable way than the landline lines.

Undoubtedly, exploiting the potential of mobile technologies in the Mozambican rural environment shows visible

\footnotetext{
1 @ Vedade, http://www.verdade.co.mz/destaques/3-newsflash/15304-movitel-e-a-terceira-operadora-de-telefonia-movel-em-mocambique. Accessed on $15 / 03 / 2018$
} 
development impacts in today's priority areas of society: democratic governance, gender, education, agriculture, health, media and climate change. In these respects, Non-Governmental Organizations adjust their action programs to these priorities.

The definition of communication policy depends on public policies established by the government. The governance process does not always respond to electoral promises or governance plans, so governance monitoring comes as an action aimed at verifying the effectiveness and efficiency of the implementation of a particular program, activity, project or public policy with a view to recommending remedial action on weaknesses to ensure that the desired objectives are achieved as described below, the use of the mobile device for the specific monitoring of electoral processes.

\subsection{Mobile and Governance Monitoring}

The high penetration rate of mobile telephony services in Mozambican society could have a profound impact on the governance system. On the one hand, mobile phones allow the connection to the Internet and social networks, consequently increasing the flow of information and sharing of ideas, which will result in a reinforced civil society, on the other, as a consequence of the first impact, require the reassessment of the governance structures.

In this context, Deliberation No. 5 / CC / 05 of 19 January on the Validation and Proclamation of the Results of the General, Presidential and Legislative Elections, on 1 and 2 December 2004, revealed irregularities, illegalities and electoral fraud $^{2}$. This observation indicates that there is a weakness in the supervision of democratic systems, which give rise to a lack of transparency during the elections.

In order to monitor the transparency of the electoral process in Mozambique, the monitoring platform for the elections called "Tcheka-lá" was launched, adapting the "Check up". It was created to involve citizens in monitoring elections, reporting incidents with the election campaign and voting process as well as monitoring ballot counts in neighborhoods or communities.

The Tcheka-lá service allows citizens to send and SMS, email, Twitter and Facebook or download Applications to report campaign issues. All the information sent goes to the central Tcheka-there and visualized in the site created for the purpose. From these reports, civil society organizations and the media can access and disseminate in their media.

At the end of the 2004 presidential and parliamentary elections, it has been proven that monitoring based on mobile phones can discourage fraud or other forms of corruption because citizens who are strengthened by their mobile capabilities can report any attempted fraud through SMS.

The involvement of the citizen in the monitoring of elections gives him the active and participative role in the political process and electoral observation, promoting electoral integrity, promoting accountability and developing participatory democracy, avoiding that the monitoring is assumed by partial entities and collaborative of fraud and electoral violence.

Likewise, in the ambit of municipal governance monitoring, a non-governmental organization called LIVANINGO implemented a monitoring and urban waste management platform, called MOPA.

Through the MOPA platform citizens report solid waste problems in their residential neighborhoods using SMS system of mobile phones, namely in the following occurrences: Truck not collected; Container to Burn; Trash out of Container; Informal Recycle Bin and (VI) and Trash in the Drainage Ditch.

The MOPA information is shared in real time to the Maputo Municipal Council, through the Department of Health and Cemeteries, and the companies of garbage collection. Through the shared information, you can have clear information

\footnotetext{
${ }^{2}$ Conselho Constitucional, DELIBERAÇÃO No 5/CC/05 de 19 de Janeiro Validação e proclamação dos resultados das eleições gerais, presidenciais e legislativas, de 1 e 2 de Dezembro de 2004. file://C:/Users/user/Downloads/Delibera\%C3\%A7\%C3\%A3o\%20n\%C2\%BA\%205CC05\%20(2).pdf. Accessed on 13/03/2018.
} 
about the real needs of the neighborhoods, as well as allow you to report to the Municipality the level of garbage collection in the residential neighborhoods so that the Municipality and companies responsible for the collection of the garbage can intervene quickly if there are problems.

The MOPA system opens up space for neighborhood residents to organize themselves to solve garbage problems based on accurate information, especially MOPA is the space for discussion and opinion about urban waste management ${ }^{3}$.

\subsection{Mobile Phone and Financial Inclusion}

Mozambique, until 2014, had 24\% of people covered by formal financial services, from a $6 \%$ in 2005 . However, actions are still underway to expand financial services for the excluded population, following the implementation of the Inclusion Strategy 2016-22, which predicts goals to reach $40 \%$ of the population with access to physical or electronic financial services by 2018 and $60 \%$ by $2022^{4}$.

Currently, about $90 \%$ of services are in urban areas. The challenge is to tailor products to low-income people, including those living in rural and peri-urban areas, who account for $70 \%$ of the unbanked population.

Mozambique is among the 25 priority countries to implement the Financial Inclusion Support Framework (FISF) by 2020. The Financial Inclusion Strategy was developed with the technical support of FISF, Technical Assistance Program of the Financial Inclusion Support Framework. This is an initiative of the World Bank Group supported by the Government of the Netherlands and the Bill and Melinda Gates Foundation. (AMB, 2016).

The purpose of the FISF is to allow access to a transaction account where adults can deposit or receive money. Especially small farmers and holders of micro, small and medium enterprises through the Mobile Banking system.

The application of Mobile Banking in the rural environment will help extend the possibilities of providing services, particularly in electronic transactions through bank transfer services, service payments, purchases, savings, etc. There is no doubt that the use of Mobile Banking to transfer money and manage the savings of poor people increases the income of families, but these programs still have a weak massification of services to the rural regions, because telecommunications companies have not yet completed the process of connectivity to the interior, worse still, some mobile money services have a prohibitive transaction fee for populations living below the poverty line.

Mobile phone use in Mozambique is advancing in both rural and urban areas, according to the national survey carried out by the Financial Sector Deepening, a non-governmental organization linked to the fi-nancial sector. According to the study, more than $80 \%$ of respondents to the survey have heard of mobile money and less than $40 \%$ have a mobile money account. These numbers are surprisingly high when compared to the results of a survey conducted in 2014, where 20.9\% of Mozambican adults had mobile money services on the phone, thanks to the entry of mKesh services from mobile operator Mcel in 2011 and services of the M-PESA mobile phone company called Vodacom in 2013. In this, the knowledge of mobile money service is lower among women, with $23.4 \%$, compared to $35.9 \%$ of men.

The legal framework of Mobile Banking is supported by Law No. 09/2004, of July 21, updated by Law 15/99 of November 1 on credit institutions. In this context, Companhia Celular de Moçambique, Mcel, introduced financial services through a mobile phone called M-Kesch. Its implementation is achieved through the Mobile Banking platform.

M-kesch's services allow easy and safe and secure access to financial services, opening a bank account and easy access to the service, without requiring a bank balance or maintenance expenses, in a similar way, the telephone company Vodacom-Mozambique has the same type of service but with the designation M-Pesa. This is a mobile financial service

\footnotetext{
3 Promoção de Boa Governação Urbana, http://www.livaningo.co.mz/promocao-da-boa-governaca-urbana/. Accessed on 13/03/2018.

4 AMB ( Associação Moçambicana de Bancos) Banca móvel acelera inclusão financeira em Moçambique,

http://www.amb.co.mz/index.php/notas-de-imoprensa/notas-de-imprensa/320-banca-movel-acelera-inclusao-financeira-em-mocambique. Accessed on $22 / 03 / 2018$
} 
that allows you to transfer and withdraw money, buy and pay for services through your cell phone.

Both the M-kesch and M-pesa services present barriers to access to citizens in rural areas. Such obstacles relate to the weak infrastructures of the Internet; lack of power grid; high transport costs; high mobile Internet costs and poor financial literacy of the population.

In the Mobile Banking services, there are two regulators: the National Communications Institute of Mozambique, telecommunications regulator, and the Central Bank, the financial regulator. Therefore, the two entities share responsibility for auditing operations that take place on this platform. Mobile banking agents such as M-Pesa and M-kesch have become microcredit institutions that fall into the role of bank intermediaries.

There is no doubt that mobile phones in rural communities help create networks of communication between citizens and government organizations. They are strategic tools for expanding financial services to the poor and creating new opportunities for citizen inclusion.

\subsection{Mobile and Agriculture}

The use of agricultural inputs is extremely low in Mozambique, but the country has enormous potential for increasing agricultural productivity through the use of improved seeds, etc. However, buying finance is a major obstacle.

A possible solution to overcome the difficulties of acquiring agricultural inputs was the use of mobile money, allowing farmers to create the habit of saving through the mobile money system, as well as offering incentives to farmers to use mobile money and, consequently, to improve productivity and income.

Although the project is promising, however, there are some challenges regarding agent retention; difficulty coordinating with partners and lack of confidence in the mobile money system.

\subsection{Mobile and Media Enhancement}

Contemporary society is witnessing the greatest phenomenon of convergence that is transforming the relations between radios and mobile phones. An example of this is the convergence of the media in the mobile phone that represents the current technological development.

In Mozambique, some radios are in the process of migrating to the mobile phone, in response to emergency and transmission of information in areas that are difficult to access, as well as to educate and keep the citizen informed on issues of environmental conservation, climate change, agricultural development, human rights, etc.

The lack of technical knowledge, public policies for the regulation of Community Radio, violation of freedom of the press and of expression among other limitations constitute a barrier for many Community Radios to adopt the digital model of transmission via streaming, whose signal is tuned by the mobile phone. Only LM Radio 87.8 radio is present; FM Mozambique Radio 97.9; Radio Maria Moçambique; Maxaquene Community Radio and Gaza Provincial Issuer, Mega Kizomba 88.9; Radio 99 FM, Radio capital 90.7 FM; Radio Moçambique 92.3 FM, Terra Verde Radio 90.0 FM; SFM 94.6 FM and Super FM 101.9. Most commercial radios, one of public nature, one religious and one community.

In the Mozambican media scene, the Community Radio is a media that has a greater national coverage, in the order of $80 \%$ of the audience in relation to commercial radio stations. They are defined as mass media, not for profit, owned by communities where they are inserted and that autonomously manage and determine the contents and formats of the respective programs.

In the universe of 28 million Mozambican inhabitants (INE, 2017), at least 18 million of the Mozambican rural population listen to RC, with the provinces of Zambézia and Nampula contributing more listeners. In numerical terms, the province of Nampula leads with a total of 18 community radios in operation (News, 2016). 
Community radio faces technical transmission difficulties and this makes it necessary to rethink the possibility of finding a way to transmit Community Radio to the mobile phone in order to reduce maintenance costs.

The potential of the mobile phone in transmitting the radio signal demonstrates efficiency and reach that classic radio could not. Streaming transmission establishes a fully differentiated broadcast structure and richer in audience reach, thanks to the Internet. However, for the effective transmission of the radio in the mobile phone, it is necessary that the classic radios are requalified for an autonomous transmission trans-mitter originating from the Internet, Webradio. A process that requires all transformation to the virtual through the process called "radiomorphosis".

In summary, the results indicate that although the social transformations of the mobile phone have an impact in some rural areas of the country, the majority of the rural population remains marginalized despite the greater accessibility to mobile telephony services.

The ministries of governance, financial inclusion, food security and the transmission of radio via mobile phones are still far from having major social impacts due to political and technological factors.

\section{Discussion}

The inability to cover fixed-line services to rural areas was outweighed by the rapid penetration of mobile phones in rural communities, as the Financial Sector Deepening survey has shown. The acceptance of the mobile device by citizens is due to its relatively inexpensive cost and its simplicity of manipulation. This has altered the economic, financial and social panorama of the interior regions of Mozambique because it has demonstrated that mobile phones are a powerful strategic tool to expand development programs, connect the poor to services and create new opportunities for civic participation in governance processes.

Reporting the theses defended by Hills, (2003) and Hamelink (2008), in contrast to the most recent study by UNESCO Reading in Mobile Era, these studies illuminate the role of the mobile phone as a factor of changes occurring in the rural environment, namely in the communicative process ; Cheers; education; bank agriculture and the media.

In parallel, the empirical studies carried out by UNDP and UNESCO, Mobile Technology and Empowerment, Turning on Mobile Learning in Africa and the Middle East Illustrative Initiatives and Policy Implications, Reading in Mobile Era, and the Mobile Africa Report 201 report, the documents report the opportunities that mobile communication technologies are opening up for new forms of communication between people and governments, giving more access to public information and basic services for all, highlighting the opportunities and challenges of the mobile telecommunications sector that is conquering the world and in Africa in a short period of time.

But the factors of change in the new world order of communication, invoked in the aforementioned studies, are not sufficiently sustainable in Mozambique if there is no internal political will, laws and a favorable democratic regime.

Financial services in Mozambique covered only 6\% of the Mozambican population in 2005; by 2014, the country had $24 \%$ of the population covered by formal financial services, but the financial inclusion framework changed, thanks to favorable legislation, technical support from the World Bank and Bill Gates Foundation.

Previously, the population did not have access to banks, bank transfer services, payment of services, etc. Data from the 2014 World Bank Survey indicated that about one-third of the population was not covered by any financial services provider. Today, progress is being made, most of the rural population is being included financially, thanks to Mobile Banking.

The results of the studies in the areas of financial inclusion and governance monitoring show signs of accelerated changes in rural areas, a scenario that requires a new framework of political and economic study that relates the impact of the mobile phone, in order to redefine public policies for digital inclusion through multisector digital literacy. 
For digital literacy in the Mozambican rural environment, several Mozambican Non-Governmental Organizations have already set up several Community Multimedia Centers, such as UNESCO and the IBIS Non-Governmental Organizations, which are real enablers of digital literacy.

When Mozambique was in the MOP, there was no way to monitor governance. After the democratic constitution, freedom of expression, elections of governmental organs, the process of monitoring of governance has become one of the instruments of verification of governmental transparency.

It was clear from the results of the study that there are success stories in Africa of governance monitoring, via electronic platforms such as Hive Colab in Uganda, Cape Town Information Technology Initiative; ISIC in South Africa; Geekcorps in Mali; Kiwanja.net; Network of Mobile Election Monitors-NMEM in Nigeria and Ushahidi in Kenya. These election monitoring systems make it possible to control voting processes at polling stations, even in the most remote areas with the least accredited observers, which reinforces the process of transparency and credibility of the electoral process. (Levingston, 2011, pp. 30-33).

In the case of governance monitoring in Mozambique, the system called "Txeca la" was created. It emerges in the context of the Mozambican Civil Society electoral ministries, a civil society that in the last 10 years has seen some growth, notably through more structured and systematic interventions, monitoring of governance through mobile phones and other digital platforms. However, electronic monitoring systems of governance are more localized and sectoral, as they lack dissemination and awareness of the citizen as a tool for exercising democracy.

Regarding financial inclusion by the Mobile Banking system, according to the latest GSMA study (2014 and 2017), as well as the UNESCO document Reading in Mobile Era, they point out the potential of the mobile phone as a resource for financial development. At the same time, its use increased 20 times in Africa in 2014, with a further 635 million subscribers, corresponding to a penetration rate of around 38 percent.

The increase in Mobile Money in Africa facilitates access to financial services and contributes to the financial inclusion of poor populations and reduces their vulnerability to economic and social shocks.

The countries with the most mobile subscribers are Nigeria, the Republic of South Africa, Kenya, the Democratic Republic of Congo and Ghana. The Internet through the mobile phone, besides allowing access to news and health information, increases the possibilities of the neediest population to increase family businesses. (Unesco, 2014, GSMA, 2014 and 2017).

The lack of money, financial illiteracy and illiteracy, which are the most notable barriers to non-use of Mobile Money services, are associated with the limitations of the expansion of financial services via mobile phones to the rural areas.

Regarding the relationship between mobile phones and radios, it is important to mention that the conver-gence announced by Jenkins (2008) allowed the radio to open new ways of transmitting its programs and to define a new concept of radio with absolutely different characteristics of analogic radio.

Community Radios in Mozambique face many political adversities: First, the lack of specific regulation, expressly recognized in the various laws, as a differentiated form of the other media because of its non-profit nature; Second, many Community Radios work with provisional licenses; Third, technical problems of signal transmission and, finally, the problem of sustainability.

The use of the mobile phone as a means of receiving the radio signal may solve the technical problem of transmitting the signal and create a closer proximity to the listener and, at the same time, allow its trans-mission outside its traditional business and broadcast environment, which introduces changes in the model of consumption of radio products.

Reception of the radio signal by the mobile phone depends, on the one hand, on a simple mobile phone with the appropriate audio reception application. On the other hand, it depends on the smartphones capable of capturing or listening to 
radio stations, in broadband. So the challenge is to build a simple interface that attracts mobile listeners. The device must contain a Radio Player application that is easy to use and can be modified according to the needs and tastes of the user. (Kemppainen, 2015).

Radio on the mobile phone is becoming a powerful medium in the rural context, thanks to the low price and massification of the device among the poor population and poor financial resources. Therefore, there is a need to study the appropriate technologies that allow it to reinforce the geographical reach of its transmission in simple and inexpensive ways.

\section{Conclusion}

After surveying the results of the study on the multifunctionality of the mobile phone in Mozambican communities, it becomes clear that the mobile phone is transforming the Mozambican political, social, economic, media and financial spheres. The mobile phone is moving beyond the role of the simple communication device to other social functionality, some exploited and others that can be explored as a means of literacy/learning, monitoring of climate change and health system.

Thanks to the cheap devices, the expansion of the electric network and the penetration of the telephone operators to the rural areas, the mobile phone can transform other social areas of the citizens' engagement.

\section{Challenges and Future Directions}

Further in-depth study of the potential of mobile phones in rural areas could explore their impact on the empowerment of rural women in the financial system, business, agriculture, and the economy as a whole.

\section{Acknowledgements}

The author is very thankful to all the associated personnel in any reference that contributed in/for the purpose of this research. Further, this research holds no conflict of interest and is not funded through any source.

\section{References}

Acist (Asssociação Empresarial de Comunicações de Portugal). Análise de Mercado de Moçambique http://www.acist.pt/publicacoes/estudos/dados_sobre_mocambique_vopen.pdf, consultado no dia 15/03/2018.

AMB (Associação Moçambicana de Bancos), (2016). Banca móvel acelera inclusão financeira em Moçambique, http://www.amb.co.mz/index.php/notas-de-imoprensa/notas-de-imprensa/320-banca-movel-acelera-inclusao-financeira-em-mocambique. Acessed on 22/03/2018.

Hamelink, C. (2008). A política de comunicação global, In LOGOS 28: Globalização e comunicação internacional. 15. (pp. 10-25). Rio de Janeiro.

GSMA (Global System for Mobile Communications), (2018). Report The Mobile Economy Sub-Saharan Africa, London, http://www.gsmamobileeconomyafrica.com/GSMA_ME_SubSaharanAfrica_Web_Singles.pdf, 28/09/2015. Accessed on 28/01/2018.

GSMA (Global System for Mobile Communications), (2014). Report The Mobile Economy Sub-Saharan Africa, London, http://www.gsmamobileeconomyafrica.com/GSMA_ME_SubSaharanAfrica_Web_Singles.pdf, 28/09/2015. Accessed on 28/01/2018.

Hill, J.(2003). Regulatory Models for in http://www.article19.org/data/files/pdfs/publications/africa-broadcasting-policy.pdf. Accessed on 23/10/2017.

INE (Instituto Nacional de Estatística) Censo populacional de 2007, Maputo.

Jenkins, H. (2008). Cultura da convergência. Ed. Aleph, São Paulo.

Levingston, S. (2011) A Evolução dos Sistemas de Informação em África: Um Caminho para a Segurança e a Estabilidade, Ed. Centro de Estudos Estratégicos de África, Wachington, http://africacenter.org/wp-content/uploads/2011/09/ARP_2_POR.pdf, Acessed on dia 30/07/2017.

Kemppainen, P. (2015), The Role of Public Service in Digitization of Radio. Journal of Media Business Studies, 9(1), 71-83. 
Noticias (2018). Dezoito Milhões de Pessoas Ouvem Rádio Comunitária, Jornal Notícias, 2016, http://www.jornalnoticias.co.mz/index.php/ciencia-e-ambiente/63946-dezoito-milhoes-de-pessoas-ouvem-radios-comunitarias.html. Acessed on 03 January 2018.

PNUD, (2012). Mobile Technologies and Empowerment, http://www.undp.org/content/undp/en/home/librarypage/democratic-governance/access_to_informationande-governance/mobiletechnologies primer.html. Accessed on 02/03/2018

UNESCO (2014) Reading in the mobile era: A study of mobile reading in developing countries. http://unesdoc.unesco.org/images/0022/002274/227436E.pdf. Accessed on 20/03/2018.

UNESCO, (2012). Turning on Mobile Learning: Illustrative Initiatives and Policy Implications in Africa and Middle East http://unesdoc.unesco.org/images/0021/002163/216359e.pdf. Accessed on 17/03/2018. 